\title{
Morphological Characteristics of the Cysts of the Maxillary Sinuses
}

\author{
Khasanov U.S., Djuraev J.A., Vokhidov U.N., Botirov A.J.
}

\begin{abstract}
Today, there are several diagnostic methods that allow you to determine the exact size and nature of periapical formations. In addition, there are studies that describe the thickening of the sinus mucosa in patients with periapical lesions and show a causal relationship. Objectives: This study was to study the morphological changes in the cysts of the maxillary sinus. Methods: 50 patients with maxillary sinus cysts were evaluated. A total of 50 maxillary sinuses (13 men and 12 women) were analyzed taking into account changes in density in the sinus cavity. The thickening of the sinus mucosa and periapical lesions was measured in the caudal-cephalic direction. The axial and sagittal axes were taken as a basis on the sagittal and coronal sections. The presence of opacities was not directly related to periapical lesions. Conclusions. Lesions of the maxillary sinus floor have been associated with chronic periapical lesions larger than $4 \mathrm{~mm}$. Clouding or thickening of the sinus mucosa was not associated with periapical lesions.

Keywords: cyst, mucous membrane, stroma, infiltration, tissue, hyperemia.
\end{abstract}

\section{INTRODUCTION}

$\mathrm{I}_{\mathrm{n}}$ flammatory diseases of the nose and paranasal sinuses in the last decade have firmly occupied the first place in the overall structure of the incidence of ENT organs, both in the analysis of accessibility to the polyclinic and in the group of patients undergoing treatment in inpatient conditions [1]. There was a significant increase in the number of diseases of the nose and paranasal sinuses both in absolute numbers and their share in the structure of the general ENT - morbidity, which annually increased by $1.5-2 \%$ and reached $52.7 \%$ [2]. The relevance of studying the problem of sinusitis is also due to the fact that it goes far beyond the scope of otorhinolaryngology and is closely related to bronchopulmonary pathology, allergization of the body and changes in local and humoral immunity [3]. Sinus cysts are one of the most common diseases in clinical practice. According to the classification of sinusitis, adopted in Ufa in 1997, cysts are a chronic form of sinusitis. Cysts of the maxillary sinuses are a very common disease that is often an incidental clinical finding on radiography and computed tomography of the paranasal sinuses [4].

Manuscript received on 12 April 2021 | Revised Manuscript received on 16 April 2021 | Manuscript Accepted on 15 June 2021 | Manuscript published on 30 June 2021.

* Correspondence Author Tashkent Medical Academy

Djuraev J.A.*, Department of otolaryngology and stomatology Tashkent Medical Academy

Vokhidov U.N., Department of otolaryngology and stomatology Tashkent Medical Academy

Botirov A.J., Department of otolaryngology and stomatology Tashkent Medical Academy

(C) The Authors. Published by Lattice Science Publication (LSP). This is an open access article under the CC-BY-NC-ND license (http://creativecommons.org/licenses/by-nc-nd/4.0/)
Khasanov U.S., Department of otolaryngology and stomatology

At the same time, there are isolated reports on the localization of cysts in the frontal and sphenoid sinuses [5]. The diagnosis of cysts of the sphenoid sinus is especially difficult, since the known X-ray packing does not allow them to be diagnosed. The problem of diagnosing cysts of the paranasal sinuses was resolved with the introduction of computed tomography into practice [6]. The nature of the headache and general complaints do not depend on the size of the cyst. Large cysts located in the lower parts of the maxillary sinus may be asymptomatic, while a small cyst located on the upper wall, in the area of the second branch of the trigeminal nerve, often causes headaches $[7,8]$. To date, only a few studies have been devoted to the morphogenesis of paranasal sinus cysts [9].

In foreign literature, the main attention is paid to odontogenic and dysontogenetic cysts [10,11]. Despite the important place occupied by paranasal sinus cysts in otorhinolaryngological practice, only a small number of works have been devoted to the issue of their modem methods of surgical treatment in recent years. The introduction of microscopic and endoscopic techniques into practice made it possible for the operating physician to analyze in detail all endonasal anatomical stmctures, assessing their relationship and role in the development of the pathological condition [12].

From the anatomical point of view, the nasal cavity is the most complexly structured organ; the functional significance of many endonasal anatomical structures is not entirely clear to this day. Before the development of endoscopic rhinosurgery, most rhinosurgeons used the traditional external approach for operations for cysts of the maxillary sinuses - the Caldwell-Luc operation or its sparing options. With the advent of endoscopic methods of rhinosinus surgery, various options for endonasal and extranasal interventions began to be performed to remove cysts of the maxillary sinus: after puncture of the canine fossa, through the lower nasal passage, after expansion of the fistula in the middle nasal passage, by the method of posterior fontanellotomy [13]. However, there are no works that summarize the experience of treating a large number of patients with paranasal sinus cysts. Also, there are not enough reports on modem methods of surgical treatment of cysts of the sphenoid and frontal sinuses.

The purpose of this study was to study the histological structure of the cysts of the maxillary sinus.

\section{MATERIAL AND METHODS}

For histological examination, the preparation of materials was carried out on a Thermo scientific STP 120, Histostar, Microm HM 325, the obtained material was carried out in stages as follows: 
registration of material, cutting, macrodescription, labeling of cassettes, distribution of material on cassettes, primary diagnosis, obtaining a preliminary diagnosis. Next comes the processing of the material, marking the glasses, obtaining the preparation and evaluating the results. Each finished micropreparation was photographed for further use in research work. In all cases, macroscopically, there was a polypoid proliferation of tissue from a light brown color to a whitish color with a smooth surface, in some cases with a bumpy uneven surface, a soft consistency, ranging in size from $1 \times 0.5 \mathrm{~cm}$ to $3 \times 2.5 \mathrm{~cm}$.

\section{RESULTS AND DISCUSSION}

Microscopically different clinical and morphological forms were characterized by certain signs of chronic inflammation and changes in the integumentary epithelium. In the second group of observations in 18 patients in the mucous membranes, there was a cystic change in the lumen of the glands with the presence of secretions in the cavities, with atrophy of the epithelium, there are small glandular tubes widi proliferation of epithelial cells, convoluted.

The integumentary epithelium is cystic and is represented by prismatic or columnar epithelium. The stroma is mostly displaced due to the expansion of the lumen of the glands, in places uneven inflammatory cell infiltration and myxomatous changes are noted (pic.1,2,3,4).

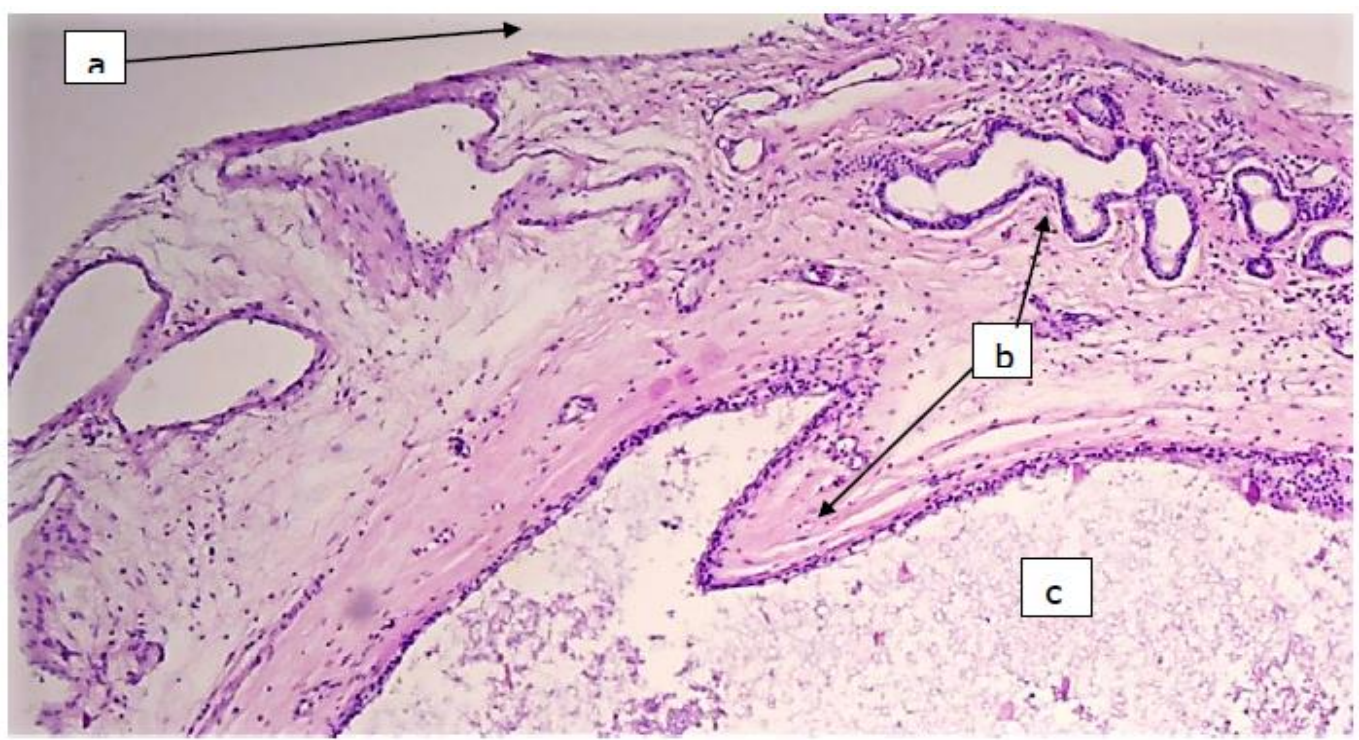

Pic. 1. Glandular cystic nasal polyp with inflammation. In the sections - a polypoid formation covered with a multilayer transitional epithelium (a), consisting of a large number of glands lined with proliferating prismatic epithelium (b). mucus (c) The stroma is edematous, represented by fibromyxomatous tissue with abundant lymphoplasmacytic and leukocytic infiltration. Hematoxylin and eosin staining. Lens mag. x10.0

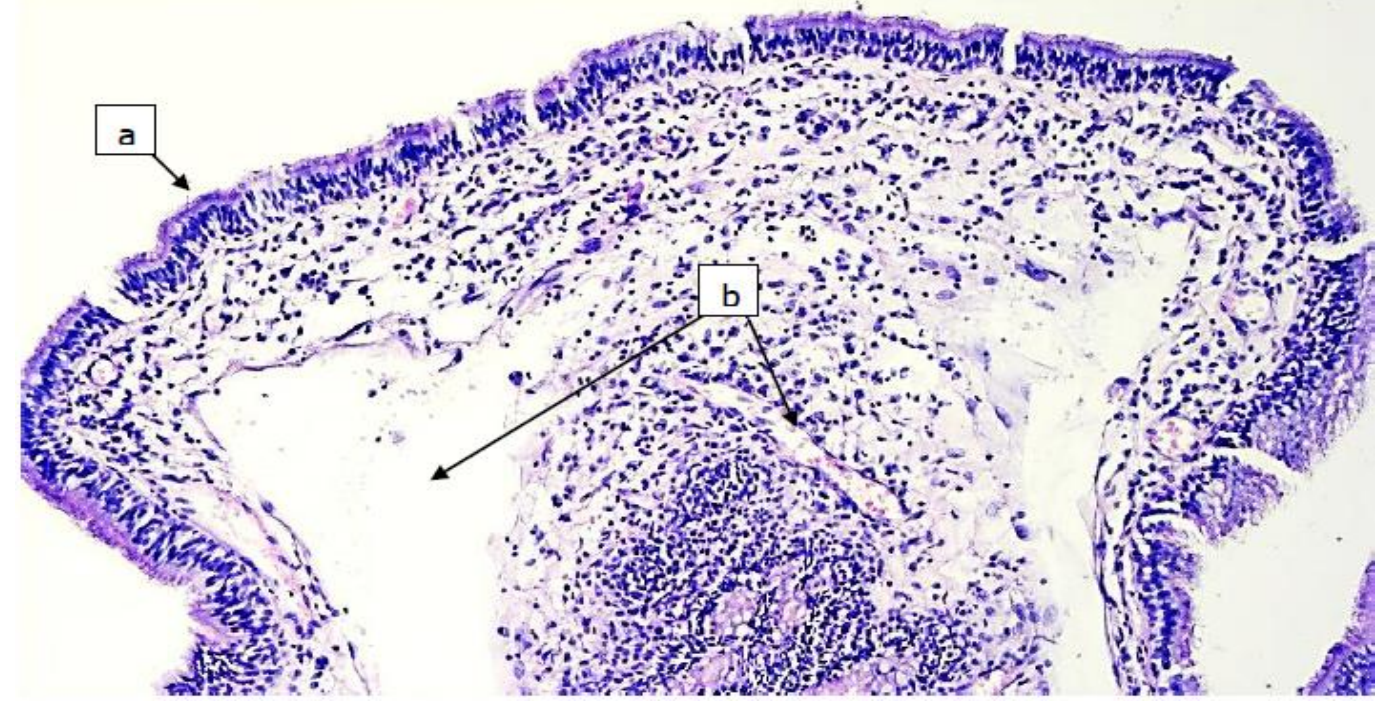

Pic. 2. Respiratory cyst with foci of inflammation, the cyst wall is lined with respiratory epithelium with foci of proliferation and desquamation (a). The stroma is represented by fibrovascular tissue with hyperemia, diffuse inflammatory infiltration of a mixed nature. There is also mucus in the cystic cavity (b). Hematoxylin and eosin staining. Lens mag. x10.0

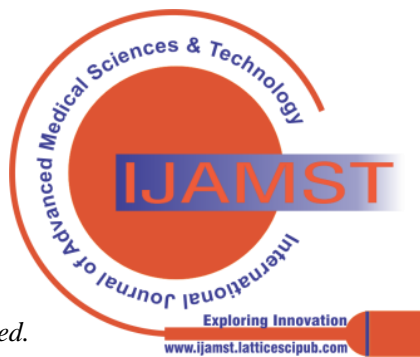




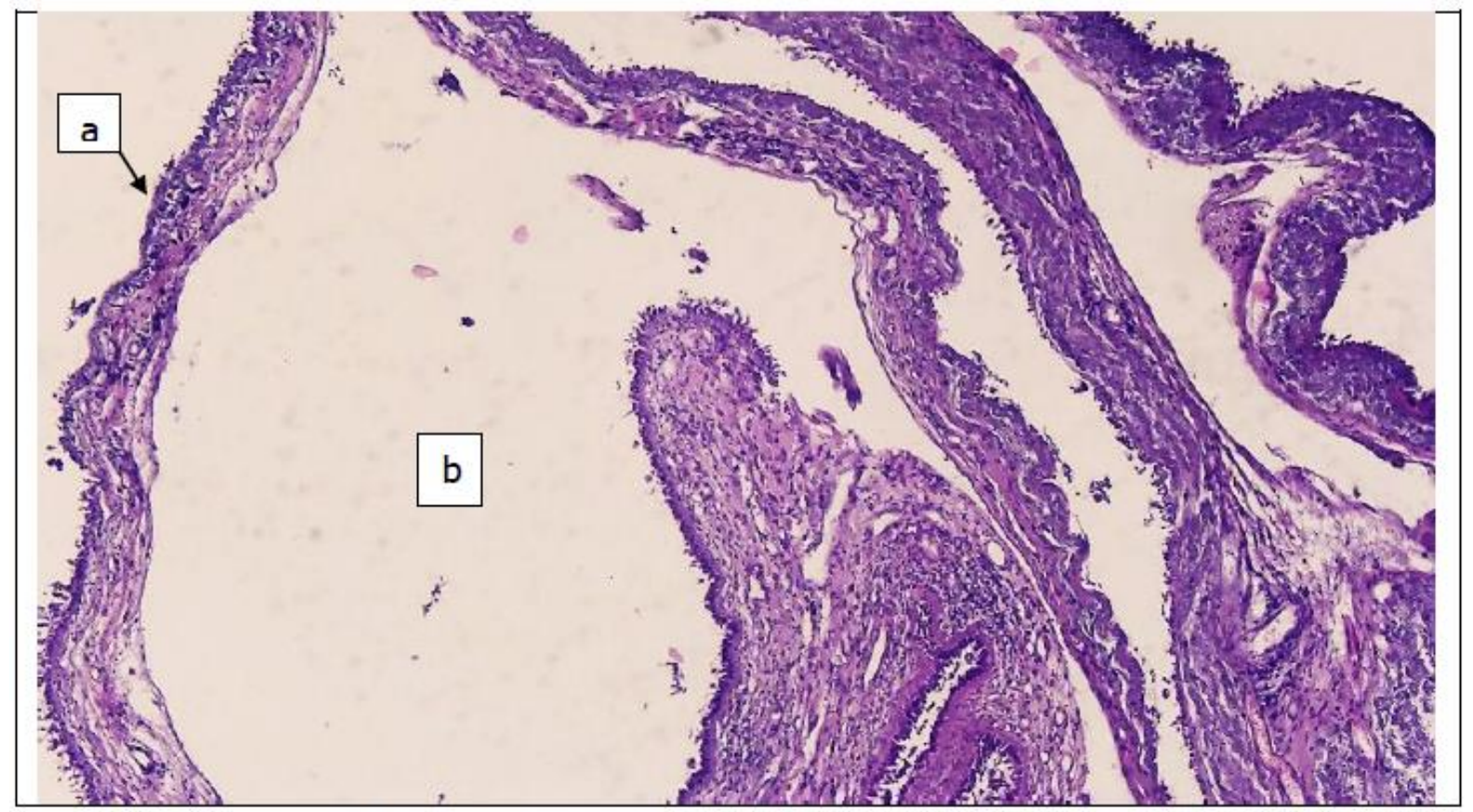

Pic. 3. Mucous cyst of inflammatory genesis.

The wall of the cyst is lined with a cylindrical multilayer epithelium (a) with foci of desquamation, in the lumen of the cysts there is homogeneous, and in some places foamy, eosinophilic contents (b). Staining with hematoxylin and eosin.

Lens mag. x10.0

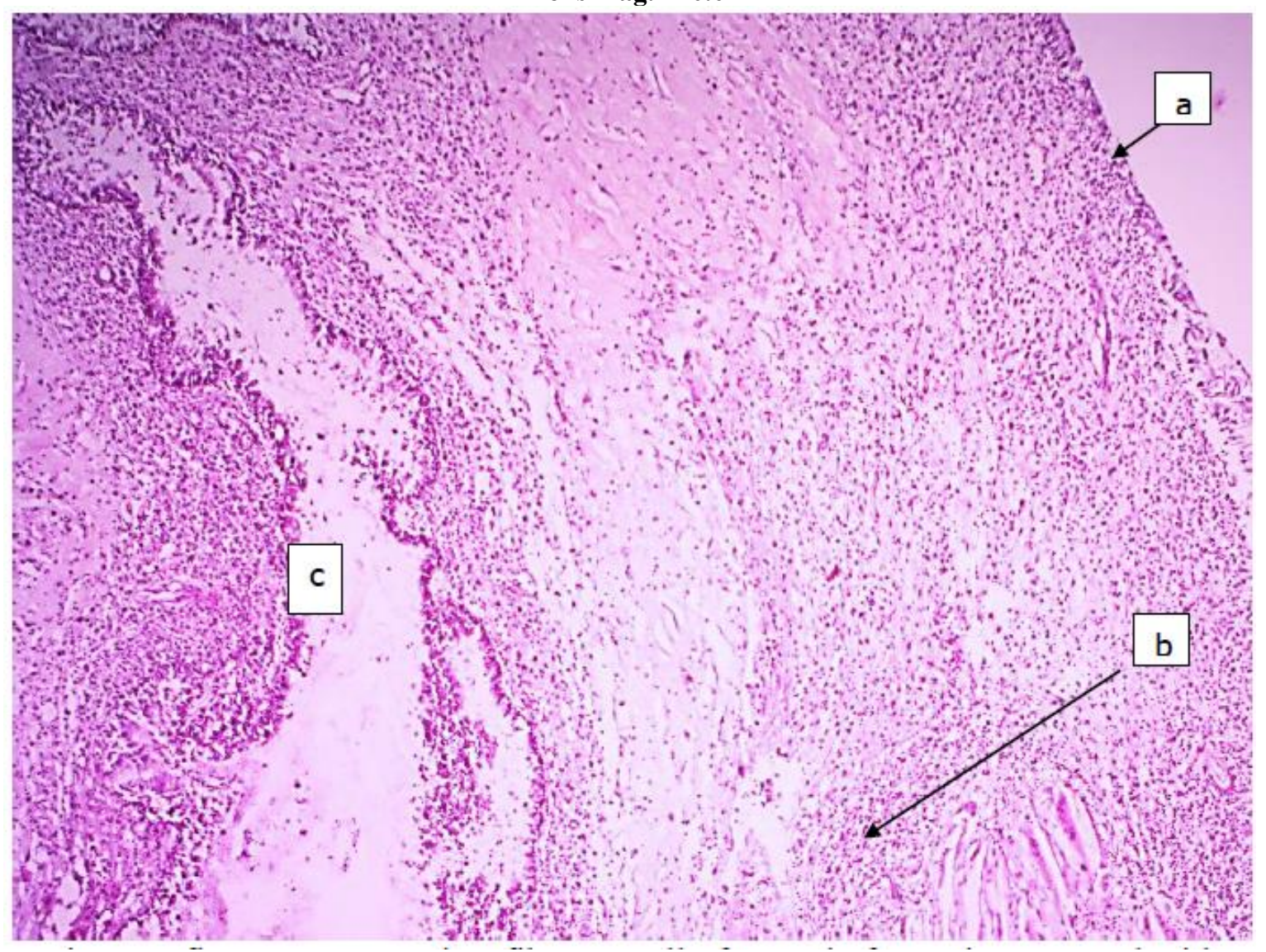

Pic. 4. Inflammatory cyst is a fibrous wall of a cystic formation covered with metaplastic multi-row epithelium (a).

Elements of acute inflammation with its destruction are found in the integumentary epithelium. There is also leukocyte infiltration in the fibrous stroma (b). Cystic-altered gland (c). Hematoxylin and eosin staining. Lens mag. $\mathbf{x 1 0 . 0}$

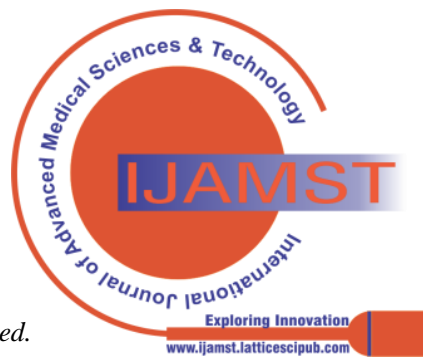


According to the results of histological examination of the second group of patients, it can be noted that morphological changes are mainly characterized by cystic lesions of the mucous glands, as well as the integumentary epithelium with focal or diffuse inflammatory cell infiltration.

\section{CONCLUSION}

Thus, the above-described morphological changes in the nasal mucosa and paranasal sinuses, both in the first and second groups, characterize changes associated with a prolonged course of the inflammatory process, a violation of the structural architectonics of the nasal passages, associated with epithelial hyperplasia, mucosal outgrowth and cystic formations, as well as the presence of elements of inflammation, in some cases, abundant secretion, which is accompanied by a violation of natural respiration, leads to the development of prolonged hypoxia. All of the above disorders are accompanied by a decrease in the function of various systems against the background of hypoxia, especially the function of the brain. The obtained results of the morphological study give a detailed description of changes in the mucous membranes and clinical signs, make it possible to assess the risk of developing chronic polyposis rhinosinusitis, and also to prevent relapses of the disease.

\section{REFERENCES}

1. Jadhav P. et al. Adenoid cystic carcinoma mimicking benign mucosal cyst of maxillary sinus //Journal of Dental Research and Review. 2016. - T. 3. - №. 2. — C. 72. [CrossRef]

2. Kim Y., Choi B. E., Ko S. O. Conservative approach to recurrent calcifying cystic odontogenic tumor occupying the maxillary sinus: a case report //Journal of the Korean Association of Oral and Maxillofacial Surgeons. - 2016. — T. 42. — №. 5. - C. 315-320. [CrossRef]

3. McMullen P. D. et al. Aneurysmal bone cyst of the maxillary sinus literature //Head and Neck Pathology. - 2019. - T. 13. - №. 3. - C. 281285. [CrossRef]

4. Misra S. R., Mohanty N. Calcified shell in the maxillary antrum: An interesting imaging characteristic of an antral cyst //Journal of Oral Biology and Craniofacial Research. - 2020. - T. 10. - №. 4. - C. 329332. [CrossRef]

5. Niederquell B. M. et al. Bilateral postoperative cyst after maxillary sinus surgery: report of a case and systematic review of the literature //Case reports in dentistry. - 2016. — T. 2016. [CrossRef] Postoperative Maxillary Cyst: A Case Report With a 13-Year FollowUp //Journal of Oral Implantology. - 2020. -T. 46. - №. 2. - C. 133-138. [CrossRef]

7. Sahoo N. K. et al. Dermoid cysts of maxillofacial region //medical journal armed forces india. - 2015. - T. 71. - C. S389-S394. [CrossRef]

8. Sharma A. et al. Clinical Characteristics of Postoperative Maxillary Cyst //Journal of Korean Dental Science. — 2017. — T. 10. — №. 2. - C. 60-65.

9. Siwach P. et al. Postoperative maxillary cyst //Indian Journal of Dental Research. - 2020. - T. 31. - №. 1. - C. 157. [CrossRef]

10. Troeltzsch $M$. et al. Etiology and clinical characteristics of symptomatic unilateral maxillary sinusitis: A review of 174 cases //Journal of Cranio-Maxillofacial Surgery. - 2015. - T. 43. - №. 8. - C. 1522-1529. [CrossRef]

11. Yamamoto S. et al. Surgical ciliated cyst following maxillary sinus floor augmentation: a case report //Journal of Oral Implantology. 2017. — T. 43. — №. 5. - C. 360-364. [CrossRef]

12. Yu H., Qiu L. Histological and clinical outcomes of lateral sinus floor elevation with simultaneous removal of a maxillary sinus pseudocys //Clinical Implant Dentistry and Related Research. - 2019. - T. 21. - №. 1. - C. 94-100. [CrossRef]

13. Botirov A. J. et al. Clinical and morphological results of xenografts to use in myringoplasty //The International Tinnitus Journal. - 2020. - T 24. 一 №. 1. - C. 1 -6. with USP6 rearrangement: case report of a rare entity and review of the

6. Park W. B. et al. Successful Management of Dental Implants in

\section{AUTHORS PROFILE}

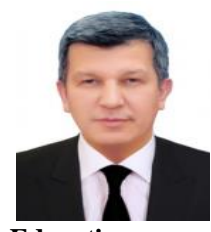

Khasanov Ulugbek Saidakramovich, DSc, Professor of the Department Otolaryngology and dentistry, Tashkent Medical Academy, Republic of Uzbekistan, E-mail: ukhasanov@yahoo.com, phone:

Education:

- $\quad$ 1985-1994 yy. - student of treatment faculty of 1-Tashkent State Medical Institute

- 1994-1996 yy. - Clinical resident of the department of ENT diseases of 1-Tashkent State Medical Institute

Working experience:

- 1996-1999 yy. - PhD student, department of ENT diseases, 1 Tashkent State Medical Institute

- 1999-2005 yy. - assistant teacher, department of ENT diseases, 1-Tashkent State Medical Institute

- 2005-2008 yy. - doctoral student, department of ENT diseases, Tashkent Medical Academy

- 2008-2010 yy. - assistant teacher, department of ENT of diseases, Tashkent Medical Academy

- 2010-2014 yy. - associate professor, department of ENT diseases, Tashkent Medical Academy

- 2014 г. - at pr. - head of department otolaryngology and stomatology of Tashkent Medical Academy

Scientific activity:

- In 1999 defended thesis on "Improving the effectiveness of retreatment in operated patients for chronic stenosis of the larynx and trachea."

- In 2008 defended doctoral dissertation on the topic "Clinical and pathogenetic features of chronic inflammatory diseases of the larynx and their treatment".

Main areas of practice:

- $\quad$ Functional Endoscopic Sinus Surgery;

- Tympanoplasty;

- Rhinoseptoplasty;

- $\quad$ Larynx Surgery;

Main directions of scientific activity:

- Studies of clinical and genetic features of diseases of ENT organs

Publications:

- Хасанов У.С., Вохидов Распространённостьполипозногопроцесса больныххроническимполипознымриносинуситом Днимолодыхучёных. Материалынаучнопрактическойконференции. 9-10 апрель 2013, Ташкент. С. 75-76

- Хасанов У.С., Вохидов Рольморфологическогоисследованияприхроническихполипозных риносинуситах // Днимолодыхучёных. Материалынаучнопрактическойконференции. 9-10 апрель 2013, Ташкент. С. 76-77

- Khasanov U.S., Vokhidov U.N. Efficacy of mometasone furoate in chronic polypoid rhinosinusitis // $2^{\text {nd }}$ Meeting of European Academy of ORL-HNS and CE ORL-HNS. Otorhinolaryngology \& Head and Neck surgery. 27-30 april 2013, Nice, France, PR63

- Khasanov U.S., Vokhidov U.N. Topical corticosteroids in the treatment of chronic polypoid rhinosinusitis // IFOS. 20 th World Congress. Innovation and Integration in ORL-HNS. 1-5 june 2013, Seoul, Korea, EP200

- Khasanov U.S., Vokhidov U.N. Morphological types of chronic rhinosinusitis with nasal polyps // IFOS. $20^{\text {th }}$ World Congress. Innovation and Integration in ORL-HNS. 1-5 june 2013, Seoul, Korea, EP191

- Khasanov U.S., Vokhidov U.N. Tactics on treatment of chronic polypoid rhinosinusitis // Topical issues of theoretical and practical medicine. Materials of the second scientific-practical conference. Part I. 2013, Tashkent. P 151-153

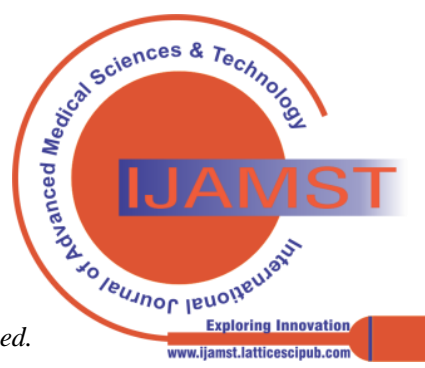


- Хасанов

У.C.,

Вохидов

У.H.

Аспектылеченияполипозногориносинусита

Актуальныевопросыфармацевтики и медицинскойнауки и практики. «Новыеаспектымедицины и фармации-2013» 73 Всеукраинскаянаучно-практическаяконференциямолодыхучёных и студентов с международнымучастием, посвященнаяДнюнауки. 16-17 мая, 2013, Запорожье, Украина. С 73

- Хасанов У.С., Вохидов иносинусита // МедицинскийжурналУзбекистана. №3, 2013, Ташкент. C 44-46

- Хасанов У.С., Вохидов У.Н Компьютертомографиянингсурункалиполипозриносинуситташхи сотидагиурни // МедицинскийжурналУзбекистана. №3, 2013, Ташкент. С 38-40

- Хасанов У.С., Вохидов Использованиесовременнойэндоскопии оториноларингологии» $\mathrm{V}$ практическаяконференцияоториноларин-

гологовцентральногофедеральногоокругаРоссийскойФедерации, гологии МОНИКИ и 75-летию соднярожденияпрофессора В.Г. Зенгера, Москва, 2013

- Хасанов У.С., Вохидов У.Н., Расулова Н.Ш. Рольэндоскопии в диагностике и лечениихроническогополипозногориносинусита // МедицинскийжурналУзбекистана. Ташкент.- 2013.- №6.- С. 43 46 У.C.,

Вохидов

У.H.

Цитокиновыйстатусприхроническомполипозномриносинусите //

НаучнопрактическийжурналРоссийскогообществаринологов. Москва.2013.- №2.- C. 69

- Хасанов Y.C., Вохидов У.H. Аспектыкомплексноголеченияхроническогополипозногориносин усита // Российскаяринология. НаучнопрактическийжурналРоссийскогообществаринологов. Москва.№2.- 2013.- C. 63

- Хасанов У.С., Вохидов У.Н. Показателицитокинов IL-2, IL-4, ILсывороткекровиприразличныхформаххроническихполипозныхри носинуситов // Российскаяоториноларингология. СанктПетербург.- 2014.-№1 (68).- С. 30-33

- Хасанов У.С., Вохидов У.Н. Сурункалиполипозриносинусит: замонавийдаволашуслублари // Журналтеоретической и клиническоймедицины. Ташкент.- 2014.- №3.- Том 1.- С. 259-262

- Хасанов У.С., Вохидов У.Н. К вопросу о тактикелеченияхроническихполипозныхриносинуситов // Сборникматериалов. 78-я итоговаянаучнопрактическаяконференция с международнымучастием, посвящённая 95-летию соднярожденияпрофессора Ю.М. Лубенского. Красноярск.-22-25 апреля 2014.- С.114

- Khasanov U.S., Vokhidov U.N. Dynamic changes of serum IL-2 during complex immunotherapy of chronic polypoid rhinosinusitis // $25^{\text {th }}$ Congress of the European Rhinologic Society. Amsterdam, Netherlands.- June 2014.-Vol.52.- Suppl. 25- ERS-1093

- Хасанов У.С., Вохидов У.Н. ПоказательІgЕ в сывороткекрови у больных с хроническимиполипознымириносинуситами // ВестникРоссийскогоГосударственногомедицинскогоуниверситет a. IX Международная (XVIII Всероссийская) Пироговскаянаучнаямедицинскаяконференциястудентов молодыхучёных. Москва.- 16 мая 2014 г.- .№2.- 2014.- С.327

$\begin{array}{llll}\text { - Хасанов У.С., } & \text { Вохидов }\end{array}$ Сурункалиполипозриносинуситэтиопатогенезигазамонавийёнда шув // МедицинскийжурналУзбекистана. Ташкент.- 2014.- №4.C. 61-64

- Хасанов У.С., Вохидов У.Н., Исмаилова А.А. Клиникоиммунологическиеаспектыхроническогорецидивирующегополип озногориносинусита // Журналтеоретической и клиническоймедицины. Ташкент.- 2014.- №4.- С. 92-95

- Хасанов У.С., Акрамова Д.Т, Вохидов У.Н., Исмаилова А.А. Измененияцитокинов ИЛ-2, ИЛ-4, ИЛ-8и IgE в сывороткекровиприразличныхформаххроническихполипозныхри носинуситов // ВестникТашкентскоймедицинскойакадемии. Ташкент.- 2014.- №2.- С. 62-64

- Хасанов У.С., Вохидов У.Н. Сурункалиполипозриносинуситларташхисотидавакомплексдавол ашдамикробиологиктекширувнингахамияти Принципылеченияхроническогорецидивирующегополипозногор лечениихроническогополипозногориносинусита // «Актуальное в посвящённая 140-летию образованияклиникиоториноларинРоссийскаяринология.

ВестникТашкентскоймедицинскойакадемии. Ташкент.- 2014. №3.- C. 51-54

- Хасанов У.С., Вохидов У.Н. Оценкаэффективностипротиворецидивноголечениябольных хроническимполипознымриносинуситом // Материалы V международной (XII итоговой) научнопрактическойконференциимолодыхучёных, посвящённой 70летию ЮУГМУ. -Челябинск. - 2 октябрь 2014 г. - С. 38-40

- Хасанов У.С., Вохидов У.Н., Шамсиев Д.Ф. Сурункалиполипозриносинуситнингтурлишаклларидабурунбушшл иғишиллиққаватинингморфологиквафункционалхусусиятлари // Стоматология. Среднеазиатскийнаучно-практическийжурнал.- № 3-4.- 2014.- C. 94-99

- Хасанов У.С Вохидов У.H. Бурунвабурунёндошбушликларикасалликларидаяллигланишгака ршидавонингимкониятлари // Стоматология Среднеазиатскийнаучно-практическийжурнал.- № 3-4.- 2014. C.94-99

- Хасанов У.С., Вохидов У.Н. Данныесравненияретроспективных и проспективныхгруппбольных с хроническимполипознымриносинуситом // Folia otorhinolaryngologiae et pathologiaerespiratoriae. -№3.-2014.- C. 10-16

- Хасанов У.С., Вохидов У.Н. Оценкаданныхаллергологическогоисследованиябольных

хроническимполипознымриносинуситом

ДокладыакадемиинаукРеспубликиУзбекистан. Ташкент, 2014. №4. - C. 91-93

- Khasanov U.S., Vokhidov U.N., Sultonov D.M., Shodiyev J.A., VokhidovN.Kh. Indicators of IgE in Blood of Patients with Chronic polypoid rhinosinusitis // 2015 International Congress of Korean Society of Otorhinolaryngology-Head \& Neck Surgery in conjunction with 89th Annual Congress of Korean Society of Otorhinolaryngology-Head \& Neck Surgery 2015 Spring Meeting of Korean Society of Otorhinolaryngo-logic Clinicians, 24-26 April.2015.- P. 175-176

- Хасанов У.С., Вохидов У.Н., Шарипов С.С., Джураев Ж.А. Сравнительнаяоценкаметодовконсервативноголеченияхроническ огополипозногориносинусита

«Оториноларингологиянингзамонавиййуналишлари» мавзусидагиУзбекистоноториноларингологларнинг Съезди.,12-13 май, Тошкент, 2015.- С. 95

- Khasanov U.S., Vokhidov U.N., Djuraev J.A., Mukhiddinov Z.N. Laser therapy in diseases of paranasal sinuses // «Оториноларингологиянингзамонавиййуналишлари» мавзусидагиУзбекистоноториноларингологларнинг Съезди.,12-13 май, Тошкент, 2015.-C.53-54

- Khasanov U.S., Sultonov D.M., Vokhidov U.N. Differentive estimation of treatment of sleep apnea // «Оториноларингологиянингзамонавиййуналишлари» мавзусидагиУзбекистоноториноларингологларнинг Съезди.,12-13 май, Тошкент, 2015.-С.130

- Khasanov U.S., Vokhidov U.N. Features of angiogenesis in various types of chronic polypoid rhinosinusitis // Стоматология Среднеазиатскийнаучно-практическийжурнал.- № 3.- 2015. C.101-103

- Khasanov U.S., Vokhidov U.N., Djuraev J.A., Sultonov D.M., Ernazarov J.G. The local immunity in tissues of various forms of nasal polyps // Allergy. European journal of allergy and clinical immunology. Abstracts from the European Academy of Allergy and Clinical Immunology Congress. - Vienna, Austria. - 11-15 June 2016. - Volume 71. - Suppl. 102. - P. 121

- Хасанов У.С., Вохидов Аллергологическиеизмененияприполипозномриносинусите // Материалы XIX съездаоториноларин-гологовРоссии. - Казань. 12-15 апреля 2016 г. - С. 423

- Khasanov U.S., Vokhidov U.N., Djuraev J.A., Sultonov D.M., Sobirov S.S. Estimation of data of specific allergic research in chronic polypoid rhinosinusitis // МолодойУченый. - Май 2016 г. №9(113). - C. 374-375

- Хасанов У.С., Вохидов Оценкакровоснабжениястромыносовыхполипов // Материалы V Петербургскогофорумаоториноларин-гологовРоссии. IV Всероссийскийконгресспослуховойимплантации с международнымучастием. Петербург. -2016 г. - С. 318 
- Хасанов

У.C.,

Вохидов

У.H.

Особенностистроенияретикулярныхволоконприхроническомпол ипозномриносинусите

«Оториноларингологиядазамонавийилмий-

амалийтехнологиялар»

Узбекистоноториноларингологлариконференциясиматериаллари, Бухоро, 19-20 май 2017 йил. - С. 83-84

- Хасанов У.С., Вохидов У.Н. Иммуногистохимическаяоценкавиментиномстромыполиповноса

«Оториноларингологиядазамонавийилмийамалийтехнологиялар»

Узбекистоноториноларингологлариконференциясиматериаллари, Бухоро, 19-20 май 2017 йил. - С. 84

- Khasanov U.S., Vokhidov U.N. Immunohistochemical differences of various forms of chronic polypoid rhinosinusitis // IFOS - ENT World Congress. Paris.- 24-28 June 2017. RA-CR-50

- Khasanov U.S., Vokhidov U.N. Levels of IgE in the periferic blood of patients with different forms of chronic polypoid rhinosinusitis / IFOS - ENT World Congress. Paris.- 24-28 June 2017. RA-CR-55

- Khasanov U.S., Vokhidov U.N. Local and overall IL-2, IL-4, IL-8 in the patients with chronic "neutrophilic" polypoid rhinosinusitis // IFOS - ENT World Congress. Paris.- 24-28 June 2017. RA-CR-56

- Khasanov U.S., Vokhidov U.N. Condition of IL-2, IL-4, IL-8 and IgE in patients with chronic polypoid rhinosinusitis // Rhinology World Congress.- Hong Kong.-1-3 September 2017. PP1017

- Khasanov U.S., Vokhidov U.N., Djuraev J.A. The prevalence of chronic inflammatory diseases of the nose and paranasal sinuses in patients with myocarditis // European Science Review. - №5-6, MayJune, 2018. - 147-149

- Khasanov U.S., Sharipov S.S., Vokhidov U.N. Modern aspects of treatment of rhonchopathy // European Science Review. - №5-6, May-June, 2018. - 225-228

- Хасанов У.С., Вохидов У.Н., Джураев Ж.А. Результатыэндоскопическогоисследованияприхроническихвоспа лительныхзаболеванияхноса и околоносовыхпазух // Стоматология. Научно-практическийжурнал. №2, 2018 (71).C. $86-88$

- Хасанов y.C., Вохидов У.H.

Рольметодаимпрегнированиясеребромприиммуногистохимическомисследованииполиповноса Российскаяоториноларингология. практическийжурнал. №1 (92), 2018.-С.34-37

- Хасанов У.С., Вохидов У.Н., Султонов Д.М. Рольоценкикачестважизнибольных различнымиформамихроническогополипозногориносинусита // МедицинскийжурналУзбекистана. Научно-практическийжурнал. №1, 2018.-С.32-35

- Хасанов У.С., Джураев Ж.А., Вохидов У.Н., Абдуллаев Т.А. Биохимическиеизменения кровипривоспалительныхзаболеванияхноса околоносовыхпазух у больных с миокардитами МедицинскийжурналУзбекистана. Научно-практическийжурнал. №3, 2018.-C.18-20

- Хасанов У.С., Вохидов У.Н., Джураев Ж.А. Оценкауровнягипоксии в крови у больных с заболеванияминоса и околоносовыхпазухнафонемиокардита // Стоматология. Научно-практическийжурнал. №3, 2018 (72).-С.82-84

- Хасанов У.С., Вохидов У.Н., Шарипов С.С. Распространённость ЛОР-патологии у больных с ронхопатией // Стоматология. Научно-практическийжурнал. №3, 2018 (72).-С.85-87

- Хасанов У.С., Вохидов У.Н. Ронхопатияфонида ЛОРСтоматология. Научно-практическийжурнал. №3, 2018 (72).C.87-89

- Хасанов У.С., Вохидов У.Н., Джураев Ж.А. Оптимизациядиагностикихроническихвоспалительныхзаболеван ийноса и околоносовыхпазух у больных с миокардитом // International scientific review of the problems and prospects of modern science and education. Boston, USA. - November 22-23. 2018. - P. 95-96

- Хасанов У.С., Вохидов У.Н., Шарипов С.С. ЛОРаъзоларикасалликларибўлганбеморлардаронхопатияниташхисоти даполисомнографиянингроли // Биологияватиббиёт. Халқароилмийжурнал. №4, (104) -С.119-121

- Khasanov U.S., Vokhidov U.N., Sharipov S.S. Use of modern technologies in the diagnostics of ronchopathy // European Science Review. - №11-12, November-December, 2018. - P. 81-83

- Khasanov U.S., Vokhidov U.N., Djuraev J.A. Condition of the nose cavity in chronic inflammatory diseases of the nose and central аъзоларикасалликларибўлганбеморлардахаётсифатинибахолаш //

infrastructure sinus in patients with myocarditis // European Science. - №9 (41), November, 2018. - P. 50-52

- Хасанов У.С., Вохидов У.Н., Шарипов С.С. Рольпатологииноса и глотки в развитиихрапа // International scientific review of the problems and prospects of modern science and education. Boston, USA. - January 21-22. - 2019. - P. 85-86

- Хасанов У.С., Вохидов У.Н., Шарипов С.С. Оптимизациядиагностикиронхопатии у пациентов с заболеваниями ЛОР-органов // XLVIII International correspondence scientific and practical conference. European research: Innovation in science, education and technology. London, Great Britain. - January 24-25. - 2019. - P. 75-76

- Хасанов У.С., Вохидов У.Н., Джураев Ж.А Распространённостьполипозногориносинусита // VIаяЕвропейскаяАссамблеяоториноларин-гологов с международнымучастием. Биологияватиббиётмуаммолари. Халқароилмийжурнал, №3.1 (112) 2019.-С.31

- Khasanov U.S., Vokhidov U.N., Djuraev J.A. Etiopatogenesis of chronic polypoid rhinosinusitis // VIаяЕвропейскаяАссамблеяоториноларин-гологов с международнымучастием. Биологияватиббиётмуаммолари. Халқароилмийжурнал, №3.1 (112) 2019.-С.110-111

- Хасанов У.С., Шарипов С.С., Вохидов У.Н. Результатыактивнойриноманометрии у пациентов с $\begin{array}{llr}\text { синдромомобструктивногоапноэсна } & \text { // } & \mathrm{VI}- \\ \text { аяЕвропейскаяАссамблеяоториноларин-гологов } & \text { с } & \text { международ- }\end{array}$ нымучастием. Биологияватиббиётмуаммолари. Халқароилмийжурнал, №3.1 (112) 2019.-С.104

- Хасанов У.С., Шарипов С.С., Вохидов У.Н. Обстуктивуйкуапноэсиндроминиташхислашдаполисомнография нингроли // VI-аяЕвропейскаяАссамблеяоториноларин-гологов с международ-нымучастием. Биологияватиббиётмуаммолари. Халқароилмийжурнал, №3.1 (112) 2019.-С.109-110

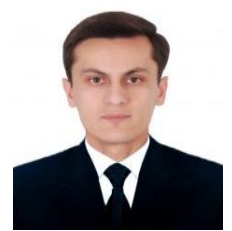

DjuraevJamolbekAbdukakharovich, $\mathrm{PhD}$, senior teacher of the Department Otolaryngology and dentistry, Tashkent Medical Academy, Republic of Uzbekistan, E-mail: drdjuraev@mail.ru, phone: +998974000351

Education:

- 2004-2011 yy. — student of treatment faculty of Tashkent medical academy

- 2011-2014 yy. - graduate student of Otorhinolaryngology of Tashkent medical academy

Labor activity:

- 2011-2014 yy. - general practitioner of 17th polyclinic of Almazar district

- 2011-2014 yy. - senior laboratory assistant, department of otolaryngology and dentistry TMA

- 2015-2019 yy. - assistant teacher, department of otolaryngology and dentistry TMA

- 2015-2016 yy. — deputy dean of treatment faculty of TMA

- 2016-2019 yy. — deputy dean of medical-prophylactic faculty of TMA

- 2019 г — at pr. - senior lecturer department of otolaryngology and dentistry TMA

Scientific activity:

- 2019 y. doctoral thesis defense (PhD) - «Optimization of treatment of diseases of nose and paranasal sinuses in patients with myocarditis».

\section{Main areas of practice:}

- $\quad$ Functional endoscopic sinus surgery

Main directions of scientific activity:

- Study of clinical and genetic aspects of polypous rhinosinusitis Awards:

- 2019 y. certificate of Rector Tuychiev L.N. Tashkent medical academy.

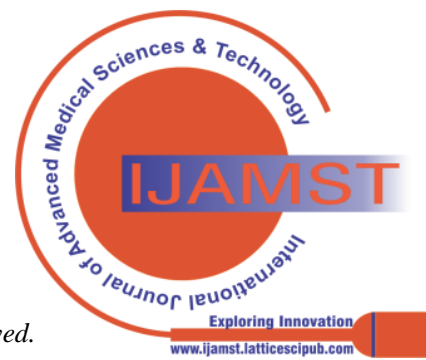


Main scientific papers over past 5 years:

- Джураев Ж.А. Improvement of comprehensive treatment vasomotor rhinitis // Topical issues of theoretical and practical medicine. I-part. Tashkent -2013y. p:47-50

- Khasanov U.S., Djuraev J.A. Current approaches to diagnosis and treatment of diseases of the nose and paranasal sinuses in patients with myocarditis // European science, 1 (23), pgs: 44-49, 2017y.

- Хасанов У.С., Джураев Ж.А., Тошпулатов Ж Особенностизаболеванийноса и околоносовыхпазух у больных с миокардитами

Молодойученыймеждународныйнаучныйжурнал, 10 (4 часть),

- Vokhidov U. N., Khasanov U. S., Djuraev J. A., Sultonov D. M., Ernazarov J. G. The local immunity in tissues of various forms of nasal polyps. // European journal of allergy and clinical immunology. Abstracts from the European Academy of Allergy and Clinical Immunology Congress. - Vienna, Austria. - 11-15 June 2015. Volume 71. - Suppl. 102. - August, 2016. - P. 121.

- Vokhidov U. N., Khasanov U. S., Djuraev J. A., Sultonov D. M., Sobirov S. S. Estimation of data of specific allergic research in chronic polypoid rhinosinusitis // Молодойучёныймеждународныйнаучныйжурнал, 9 (4 часть), 2016г., стр. 374-376

- Хасанов У.С., Вохидов У.Н., Джураев Ж.А. Результатыэндоскопическогоисследованияприхроническихвоспа лительныхзаболеванияхноса и околоносовыхпазух // Стоматология №2, 2018 (71), стр 86-88

- Джураев Ж.А., Хасанов У.С., Абдуллаев Т.А., Вохидов У.Н. Биохимическиеизменения

кровипривоспалительныхзаболеванияхноса

околоносовыхпазух у больных с миокардитами //

Ўзбекистонтиббиётжурнали

- Джураев Ж.А., Хасанов У.С., Вохидов У.Н Хроническийполипозныйриносинусит:

современныйвзгляднаэтиопатогенез, диагностику и лечение // Ўзбекистонтиббиётжурнали №4, 2019

- Джураев Ж.А., Хасанов У.С., Вохидов У.Н. Сравнительнаяоценкариноэндоскопическогоисследования у больных с полипознымриносинуситом // Ўзбекистонтиббиётжурнали №5, 2019

- Джураев Ж.А., Хасанов У.С., Вохидов У.Н. Current issues of the treatment of chronic polyposalrinosinusitis // Биомедицина и практика №7, 2019

- Джураев Ж.А., Хасанов У.С., Вохидов У.Н. Распространённостьполипозногориносинусита Биологияватиббиётмуаммоларихалкароилмийжурнал №3.1 (112) 2019 стр-31

- Джураев Ж.А., Хасанов У.С., Вохидов У.Н. Etiopatogenesis of chronic polypoid rhinosinusitis Биологияватиббиётмуаммоларихалкароилмийжурнал №3.1 (112) 2019 стр-110

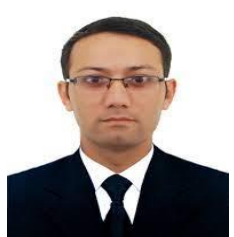

Vokhidov Ulugbek Nuridinovich, DSc, Professor of the Department Otolaryngology and dentistry, Tashkent State Dental Institute, Republic of Uzbekistan, E-mail: dr_ulugbek@list.ru, phone: +998903454582

1. Djuraev J.A., Vokhidov U.N., Khasanov U.S. The prevalence of chronic inflammatory diseases of the nose and paranasal sinuses in patients with myocarditis / European Science Review. - №56, May-June, 2018. - P. 147-149

2. Shamsiev D.F., Vokhidov U.N., Karimov O.M. Functional and morphological feautures of wound healing process in the mucosa of the nose and maxillar sinuses in the patients with chronic inflammatory diseases of paranasal sinuses / European Science Review. - №5-6, May-June, 2018. - P. 229-231

3. Sharipov S.S., Vokhidov U.N., Khasanov U.S. Modern aspects of treatment of rhonchopathy / European Science Review. - №56, May-June, 2018. - P. 225-228

4. Khasanov U.S., Vokhidov U.N., Sharipov S.S. Use of modern technologies in the diagnostics of ronchopathy / European Science Review. - №11-12, November-December, 2018. - P 81-83 2016г., стр. 547-550

5. Khasanov U.S., Vokhidov U.N., Juraev J.A. Condition of the nose cavity in chronic inflammatory diseases of the nose and central infrastructure sinus in patients with myocarditis / European Science. - №9 (41), November, 2018. - P. 50-52

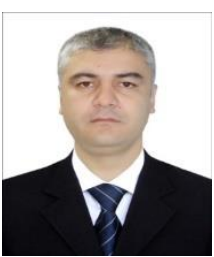

BotirovAbdurasulJumaevich, $\mathrm{PhD}$, Assistant of the Department Otolaryngology and dentistry, Tashkent Medical Academy, Republic of Uzbekistan, Email: joachffamed@mail.ru, phone:+998909701944

- 1997-2004 - student of the treatment faculty of the Second Tashkent State Medical Institute

- 2004-2007 - graduate student of Department of ENT diseases of the Tashkent Medical Academy

Labor activity:

- 2007-2010 - Assistant teacher of the Department of ENT of Diseases of the Tashkent Medical Academy

- 2010-2013 - PhD student of the Department of ENT of Diseases of the Tashkent Medical Academy

- 2013- 2016 - otolaryngologist, adult ENT department, Department of the second clinic of the Tashkent Medical Academy

- 2016 to present - assistant teacher of the ENT department of diseases of the Tashkent Medical Academy

Scientific activity:

- Clinical - experimental rationale for the use of xenograft in tympanoplasty

Main areas of practice:

- Septoplasty

- Rhinoplasty

- Tonsillectomy

- Uvuloplasty

- Adenoidectomy

- Vasotomy

- Tympanoplasty

- Radical Surgery

- Fess

- Atticoantrotomy

Main directions of scientific activity:

- The rationale for the use of auto and xenotransplant in chronic dry mesotympana

Main scientific papers over past 5 years:

- Botirov A.J., HodjanovSh.H., Rahimjanova G.A. Founding of efficiency of using xenograft in miringoplasty // Материалы IV съездаоториноларингологовУзбекистана

«Современныенаправления в оториноларингологии» Ташкент 2015 стр 16.

- Ботиров А.Ж., Маткулиев Х.М., Исроилов Р.И., Ходжанов Ш.Х. Ксенотрансплантатниэксперименталкуёнларда кулллашнинг морфологик натижалари // Материалы IV съездаоториноларингологовУзбекистана

«Современныенаправления в оториноларингологии» Ташкент 2015 стр34.

- Ботиров А.Ж. «Оториноларингология фанини ўкитишда модуль тизимини кўллашнинг ахамияти"//The collection of materials of the XII educational conferece 2016 стр 53-56.

- Ботиров А.Ж., Маткулиев Х.М. “Эффективность применения ксенотрнсплантата при тимпанопластике” // Оториноларингологияда замонавий илмий-амалий технологиялар МАТЕРИАЛЛАРИ Бухоро 2017 стр34.

- Ботиров А.Ж., Маткулиев Х.М., Исроилов Р.И "Ксенотрансплантатни куёнларда экспериментал тимпанопластикада кўллашнинг морфологик натижалари // Оториноларингологияда замонавий илмий-амалий технологиялар МАТЕРИАЛЛАРИ Бухоро 2017 стр43.

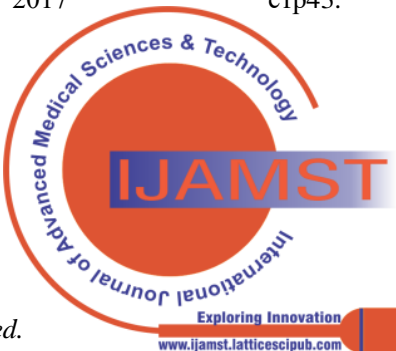


- Ботиров А.Ж., Собиров Б.Н., “Варианты доступа к барабанной перепонке при мирингопластике" // Оториноларингологияда замонавий илмий-амалий технологиялар МАТЕРИАЛЛАРИ Бухоро 2017 стр 51.

- Ботиров А.Ж., Маткулиев Х.М., Исроилов Р.И. “Морфологические результаты с применением ксенотрансплантата экспериментальным тимпанопластике" // АВИЦЕННА научный медицинский журнал Выпуск № 20 Кемерова 2018 стр 49-54.

- Ботиров А.Ж., Вахобов А.А., Абдувохидов Б.Б. "Клинические особенности вестибулярного головокружения при синдроме Меньера" // INNOVATIONS IN MEDICINE: VIEV OF YOUNG SIENTISTS Tashkent 2018 стр 165.

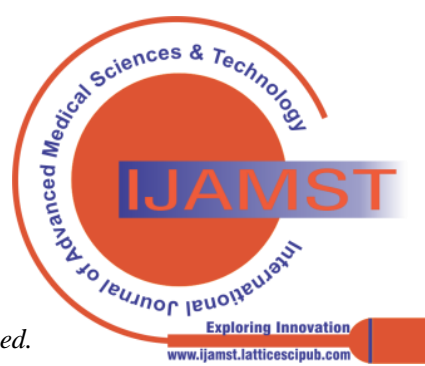

